\title{
Intracerebral Baclofen Administration Decreases Amphetamine-Induced Behavior and Neuropeptide Gene Expression in the Striatum
}

\author{
Wenxia Zhou', Adam W Mailloux' and Jacqueline F McGinty*,' \\ 'Department of Physiology and Neuroscience, Medical University of South Carolina, Charleston, SC, USA
}

In a previous study, systemic administration of the $G A B A_{B}$ receptor agonist, $R-(+)$-baclofen $(2.5 \mathrm{mg} / \mathrm{kg}$, i.p.) blocked acute amphetamine $(2.5 \mathrm{mg} / \mathrm{kg}$, i.p.)-induced rearing and neuropeptide (preprodynorphin (PPD), preprotachykinin (PPT), preproenkephalin (PPE), and secretogranin II (SGII)) mRNA expression in the striatum (Zhou et al, 2004). The purpose of the present study was to investigate the site(s) of action of these baclofen effects in the dorsal and ventral striatal circuitries. Infusion of baclofen ( $75 \mathrm{ng} / \mathrm{side})$ into the ventral tegmental area (VTA), substantia nigra (SN), nucleus accumbens (NA), caudate-putamen (Cpu), or medial prefrontal cortex (mPFC) had no effect on behavioral activity in saline-treated rats habituated to a photocell apparatus. However, intra-VTA infusion of baclofen (75 ng/ side) completely blocked, whereas intra-NA and intra-SN infusion of baclofen attenuated, amphetamine-induced vertical activity without affecting amphetamine-induced total distance traveled. In contrast, intramedial PFC and intra-CPu infusion of baclofen had no effect on behavioral activity in amphetamine-treated rats. Infusion of baclofen into the VTA, NA, or SN decreased amphetamine-induced neuropeptide gene expression in the striatum. These results indicate that $\mathrm{GABA}_{\mathrm{B}}$ receptor stimulation within the ventral striatal circuitry is involved in mediating acute amphetamine-induced behaviors and neuropeptide gene expression in the dorsal and ventral striatum. The present study provides information on the potential targets in the brain for baclofen in the initial behavioral and genomic response to amphetamine.

Neuropsychopharmacology (2005) 30, 880-890, advance online publication, 8 December 2004; doi: I0.1038/sj.npp. I 300635

Keywords: GABA ; dynorphin; enkephalin; secretogranin II; substance P; psychostimulant

\section{INTRODUCTION}

Acute administration of amphetamine causes direct stimulation of dopamine (DA) release from mesoaccumbal and nigrostriatal terminals (Zetterstrom et al, 1983; Sharp et al, 1987). This increase in striatal synaptic dopamine leads to an increase in locomotion and stereotypic behavior (Robinson and Becker, 1986; Kalivas and Stewart, 1991; White and Wolf, 1991). The increased dopamine release also leads to a cascade of events that involves the activation of neuropeptides in postsynaptic striatal neurons. The induction of striatal neuropeptides, preprodynorphin (PPD), preprotachychinin (PPT), and preproenkephalin (PPE), is well documented after acute administration of amphetamine (Wang and McGinty, 1995a, b; Zhou et al, 2004). After binding to their corresponding receptors, these peptides are

*Correspondence: Dr JF McGinty, Department of Physiology and Neuroscience, Medical University of South Carolina, 173 Ashley Avenue-Suite 403, BSB 403, Charleston, SC 29425, USA, Tel: + I 843 792 9036, Fax: + I 843792 4423, E-mail: mcginty@musc.edu Received 12 April 2004; revised I September 2004; accepted 5 October 2004

Online publication: 4 November 2004 at http://www.acnp.org/citations/ Npp I 10404040 | 68/default.pdf able to modulate the release of DA, glutamate, and acetylcholine in the striatum (Heijna et al, 1990; Guzman et al, 1993; Anderson et al, 1994; Gray et al, 1999; Rawls and McGinty, 2000). Recently, we also demonstrated that acute amphetamine increases secretogranin II (SGII) mRNA in the striatum (Gonzalez-Nicolini and McGinty, 2002; Zhou et al, 2004). SGII, a member of the chromogranin family, regulates the packaging, processing, and release of peptides and neurotransmitters (Huttner et al, 1991). Thus, these four neuropeptides are able to modify the changes in striatal neurotransmission caused by psychostimulants.

The GABA system is known to interact with and modulate DA neurotransmission in the nigrostriatal (Engberg et al, 1993) and the mesolimbic dopaminergic pathways (Kalivas et al, 1990). Three types of GABA receptors exist: $\mathrm{GABA}_{\mathrm{A}}$, $G_{A B A}$, and $G_{A B A}$. $G_{A B A}$ and $G A B A_{C}$ receptors are GABA-gated chloride channels. $G_{A B A_{B}}$ receptors are $G_{i} / G_{o}$ protein-coupled receptors that modulate signal transduction pathways, for example, inhibiting adenylate cyclase, stimulating phospholipase $\mathrm{A} 2$, activating $\mathrm{K}^{+}$channels, inhibiting voltage-dependent $\mathrm{Ca}^{2}+$ channels, and regulating inositol phospholipids hydrolysis (Bowery, 1993; Misgeld et al, 1995). $\mathrm{GABA}_{\mathrm{B}}$ receptors are enriched in areas of the brain that mediate the rewarding and activating effects of 
psychostimulants (Chu et al, 1990; Lopez-Bendito et al, 2002; Boyes and Bolam, 2003). Several investigators have demonstrated that the selective $\mathrm{GABA}_{\mathrm{B}}$ receptor agonist, baclofen, attenuates cocaine self-administration across a wide range of conditions, including multiple schedule (Shoaib et al, 1998), progressive ratio (Roberts et al, 1996), fixed ratio (Campbell et al, 1999), concurrent access (Brebner et al, 2000), and discrete trial schedules of reinforcement (Roberts and Andrews, 1997). When exposed to a videotape of drug paraphernalia, cocaine addicts taking baclofen reported reduced craving and PET imaging demonstrated reduced limbic activation (Brebner et al, 2002). Recently, a clinical trial showed that cocaine addicts receiving baclofen demonstrated significant reductions in cocaine use over those receiving placebo as indicated by urine drug screening results (Shoptaw et al, 2003). Furthermore, baclofen decreases cocaine-induced increases in extracellular dopamine (Fadda et al, 2003). Thus, the $\mathrm{GABA}_{\mathrm{B}}$ receptor agonist, baclofen, is a promising therapeutic candidate in the treatment of cocaine addiction.

Much less is known about the effects of $\mathrm{GABA}_{\mathrm{B}}$ receptor stimulation on amphetamine-induced behavioral and neurochemical responses. A previous study from our laboratory demonstrated that $\mathrm{GABA}_{\mathrm{B}}$ receptor activation by $(+)$ baclofen $(2.5 \mathrm{mg} / \mathrm{kg}$, i.p.) blocked amphetamine-induced rearing, decreased the peak level of striatal DA release, and blocked mRNA expression of PPD, PPT, PPE, and SGII in the striatum (Zhou et al, 2004). In the present study, intracerebral infusion of baclofen was used to investigate the sites of action of baclofen in major nodes of the 'motive circuit' that includes dorsal striatal-related circuitry (including substantia nigra $(\mathrm{SN})$ and caudate putamen $(\mathrm{CPu})$ ) and ventral striatal-related circuitry (including ventral tegmental area (VTA), nucleus accumbens (NA), and medial prefrontal cortex (mPFC)). We hypothesized that the $\mathrm{GABA}_{\mathrm{B}}$ receptor stimulation within key nodes of the dorsal and ventral striatal circuitries would decrease amphetamine-induced hyperactivity and striatal neuropeptide gene expression.

\section{MATERIALS AND METHODS}

\section{Animals}

Adult male Sprague-Dawley rats (250-275 g, Charles River, Raleigh, NC) were maintained two per cage on a 12-h light/ dark cycle with food and water provided ad libitum 3-7 days prior to the experiments. All animal procedures used were in strict accordance with the NIH Guide for the Care and Use of Laboratory Animals and were approved by the Institutional Animal Care and Use Committee. Following surgery, animals were housed individually and allowed at least 1 week to recover before the experiments.

\section{Surgery}

After 3-7 days of acclimation, animals were anesthetized with ketamine $\mathrm{HCl}(87.5 \mathrm{mg} / \mathrm{kg}$ Rompum; Fort Dodge Animal Health, Fort Dodge, IA) and xylazine $(5 \mathrm{mg} / \mathrm{kg}$ AnaSed; Shenandoah, Iowa) and implanted with bilateral guide cannulae (26 gauge; Small Parts Inc., Roanoke, VA) aimed at one of five brain regions according to the atlas of Paxinos and Watson (1986) (all coordinates given relative to bregma): $\mathrm{mPFC}:+3.0 \mathrm{~mm}$ antereoposterior (AP), $\pm 1.0 \mathrm{~mm}$ mediolateral (ML), and $-3.0 \mathrm{~mm}$ dorsoventral (DV); $\mathrm{CPu}$ : $+0.7 \mathrm{~mm}$ AP, $\pm 3.0 \mathrm{~mm} \mathrm{ML}$, and $-2.7 \mathrm{~mm} \mathrm{DV}$; NA: $+1.6 \mathrm{~mm}$ AP, $\pm 1.4 \mathrm{~mm} \mathrm{ML}$, and $-2.7 \mathrm{~mm} \mathrm{DV;} \mathrm{SN:}$ $-5.2 \mathrm{~mm}$ AP, $\pm 2.1 \mathrm{~mm} \mathrm{ML},-2.7 \mathrm{~mm} \mathrm{DV}$; and VTA: $-5.2 \mathrm{~mm} \mathrm{AP}, \pm 1.56 \mathrm{~mm} \mathrm{ML}$ at an angle of $6^{\circ},-7.6 \mathrm{~mm}$ DV. Guide cannulae (cut to 10 or $14 \mathrm{~mm}$ ) were lowered into place and attached to the skull via small stainless steel screws and dental acrylic. The obturators (30 gauge; Small Parts Inc.), cut to extend $0.5 \mathrm{~mm}$ shorter than the tip of each cannula, were inserted to prevent obstruction.

\section{Drug Microinjections}

Kalivas et al (1990) demonstrated that baclofen (75 ng/ $0.5 \mu \mathrm{l} /$ side) infusion into the VTA blocked DAMGO, cocaine, and amphetamine-induced hyperactivity. Thus, $75 \mathrm{ng} /$ side baclofen was used in the present study. Before injection, the obturators were removed from the guide cannulae and 30 gauge microinjection cannulae were inserted bilaterally to extend $0.5 \mathrm{~mm} \mathrm{(mPFC),} 2.8 \mathrm{~mm}$ $(\mathrm{CPu}), 3.8 \mathrm{~mm}(\mathrm{NA}), 6.0 \mathrm{~mm}(\mathrm{SN})$, or $1.0 \mathrm{~mm}$ (VTA) below the end of the guides. Before behavioral testing, rats received a bilateral infusion of either artificial cerebrospinal fluid (ACSF, which consisted of $\mathrm{KCl}$ (3.0 mM), $\mathrm{NaCl}$ (140 mM), glucose (7.4 mM), $\mathrm{CaCl}_{2} \cdot \mathrm{H}_{2} \mathrm{O}$ (1.2 mM), $\mathrm{MgCl}_{2}$ (1.0 mM), $\mathrm{NaH}_{2} \mathrm{PO}_{4}(0.27 \mathrm{mM}), \mathrm{Na}_{2} \mathrm{HPO}_{4}$ (1.2 mM), pH 7.4) or $75 \mathrm{ng} /$ side of $(+)$-baclofen into $\mathrm{mPFC}, \mathrm{CPu}, \mathrm{NAS}, \mathrm{SN}$, or VTA. All infusions were made in a volume of $0.5 \mu \mathrm{l}$ (with the exception of $\mathrm{CPu}$, in which a volume of $1.0 \mu \mathrm{l}$ was infused due to the large area) over $5 \mathrm{~min}$. After infusion, $2 \mathrm{~min}$ were allowed for adequate diffusion, then the microinjectors were removed, the obturators were replaced, and the rats were given an injection of amphetamine $(2.5 \mathrm{mg} / \mathrm{kg}$, i.p.) or saline $(1 \mathrm{ml} / \mathrm{kg}$, i.p.). Pilot experiments were performed using pontamine sky blue infused in the volumes and at the coordinates listed above to demonstrate that the extent of diffusion was limited to the region of interest.

\section{Behavior}

In each behavioral experiment, rats were randomly assigned to four different groups: ACSF + saline, ACSF + amphetamine, baclofen + saline, or baclofen + amphetamine $(n=8 /$ group). The day before the test day, the rats were habituated in Accuscan Photocell Chambers (Accuscan Instruments, Inc., Columbus, OH). Each box contained a series of 16 photocell beams measuring horizontal distance traveled and eight photocell beams measuring vertical activity. Beam breaks were continuously counted and recorded once every 5 min by a PC running VersaMax/Digiscan System Software (Accuscan Instruments, Inc.). On the test day, after $1 \mathrm{~h}$ habituation in the chamber, each rat was given an intracranial injection of ACSF or baclofen into one of the structures listed above. After $10 \mathrm{~min}$, each rat received a second injection of saline or amphetamine $(2.5 \mathrm{mg} / \mathrm{kg}$, i.p.). Both total distance traveled and vertical activity were recorded for $3 \mathrm{~h}$ after the second injection. Immediately after the test, all rats were anesthetized with Equithesin (10 mg/kg, i.p.) and decapitated. The brains were removed and frozen in isopentane at $-40^{\circ} \mathrm{C}$ and stored at $-80^{\circ} \mathrm{C}$ until they were sectioned. 


\section{In Situ Hybridization Histochemistry}

Quantitative in situ hybridization histochemistry to measure the effects of intracranially administered baclofen on amphetamine-induced PPD, PPT, PPE, and SGII mRNA expression in striatal neurons was performed as previously described (Zhou et al, 2004). Briefly, $12 \mu \mathrm{m}$ coronal sections throughout the striatum of each rat ( $n=4-8$ /group) were cut in a cryostat (four sections per slide) and thaw-mounted onto Superfrost/Plus slides (Fisher Scientific, Pittsburgh, $\mathrm{PA})$. Before hybridization, the sections were pretreated in a series of steps that fixed and defatted the tissue and blocked nonspecific hybridization. Synthetic cDNA oligodeoxynucleotide probes (48-mers) complementary to rat PPD (bases 862-909), PPT (spanning the first 16 amino acids encoded by exon 3), PPE (bases 388-435), and SGII (bases $862-903)$ were radiolabeled with ${ }^{35} \mathrm{~S}$-dATP $(1250 \mathrm{Ci} / \mathrm{mmol}$; New England Nuclear, Boston, MA) using terminal deoxynucleotide transferase (Roche Diagnostics Corp, Indianapolis, IN). Slides were incubated with $5.0 \times 10^{5} \mathrm{cpm} / 25 \mu \mathrm{l}$ hybridization buffer/section overnight $(16-20 \mathrm{~h})$ at $37^{\circ} \mathrm{C}$ in a humid environment. After incubation, slides were washed and air dried before being placed into a film cassette, along with ${ }^{14} \mathrm{C}$ standards (American Radiolabeled Chemicals, St Louis, MO), with Kodak Biomax film (Rochester, NY) for 3 days (PPE), 5 days (PPT), 7 days (SGII), or 10 days (PPD).

Quantitation of the PPD, PPT, PPE, and SGII mRNA hybridization signals was performed using NIH image 1.62 (W. Rasband, NIMH) on a Macintosh G3 as previously described (Wang and McGinty, 1995b; Zhou et al, 2004). All measurements were made unilaterally on three adjacent coronal sections ranging from 1.6 to $1.0 \mathrm{~mm}$ rostral to Bregma from each animal, matched across animals for their rostral-caudal level. For the experiments in which microinfusions were made in the $\mathrm{CPu}$ or NA, six sections at the center of each injection site were collected for Nissl staining (see below) and adjacent sections (within $75 \mu \mathrm{m}$ rostral and/ or caudal) were used for quantitation of hybridization signals.

In each experiment, the hybridization signals for all four transcripts were measured in each animal using an oval shape: $80 \times 100$ pixels in the $\mathrm{CPu}, 30 \times 70$ pixels in the NA shell, and $75 \times 75$ pixels in the NA core. The limits of the density slice option were set to eliminate background (minimum) and to avoid saturation (maximum) of the signals in each area. Quantitative changes were expressed as (1) the number of labeled pixels per area (area), (2) mean density of tissue in $\mathrm{dpm} / \mathrm{mg}$, and (3) integrated density, which is the product of area times mean density. The integrated density value more accurately depicts the area over which changes in optical density occur because we have found that mean density alone underestimates these changes (Wang and McGinty, 1995b; Zhou et al, 2004). The mean integrated density \pm SEM was calculated for each rat by averaging the values of the three adjacent coronal sections.

\section{Histology}

Six $12-\mu \mathrm{m}$ thick sections through the center of the injection site were mounted onto precleaned, charged microscope slides and stained with $0.1 \%$ thionin. The placement of each injection cannula was verified according to the rat brain atlas of Paxinos and Watson (1986). Only data from rats with correctly placed probes were analyzed.

\section{Drugs and Chemicals}

D-amphetamine sulfate and $\mathrm{R}-(+)$-baclofen hydrochloride were purchased from Sigma Chemical Co. (St Louis, MO) and dissolved in ACSF. All other chemicals used in this study were purchased from either Fisher Scientific or Sigma Chemical Co.

\section{Statistics}

Behavioral data were analyzed by calculating the area under the curve (AUC) for the activity counts plotted against time. A one-way analysis of variance (ANOVA) was performed for overall group comparisons. For the gene expression data, a two-way ANOVA was performed on the mean integrated density values. When an ANOVA F-ratio was significant, multiple comparisons were made on behavioral and gene expression data using a least squares means (LSM) test. Results were determined to be significant when $P<0.05$. All statistical calculations were made using SAS 9.0 (SAS Institute Inc., Cary, NC).

\section{RESULTS}

\section{Histology}

Figure 1 shows the injection sites of animals used in each experiment. Cannula tips in the mPFC were located in the anterior cingulate cortex ( $\mathrm{Cg} 1$ and $\mathrm{Cg} 3$ ) from Bregma 3.2 to $2.2 \mathrm{~mm}$ AP with the majority at $2.7 \mathrm{~mm}$ AP (Figure 1a). Cannula placements in the $\mathrm{CPu}$ were in the center of the caudate putamen clustered primarily between Bregma 1.2 and $0.7 \mathrm{~mm} \mathrm{AP}$ but with a few tips between 1.7 and $1.2 \mathrm{~mm}$ AP (Figure 1b). Cannula tips in the NA were located in both the core (the majority) and the shell clustered primarily between Bregma 1.7 and $1.6 \mathrm{~mm} \mathrm{AP}$ but with some tips extending to $1.0 \mathrm{~mm}$ AP (Figure $1 \mathrm{~b}$ ). Cannula placements in the VTA were medial to the medial lemniscus clustered primarily between Bregma -5.6 and $-6.3 \mathrm{~mm}$ AP (Figure 1c). Cannula tips for the $\mathrm{SN}$ were in both the reticulata and the compacta, with a majority of tips clustered primarily between Bregma -4.5 and $-5.8 \mathrm{~mm}$ AP (Figure 1c).

\section{Intra-VTA, Intra-NA, and Intra-SN Infusion of Baclofen Decreased Amphetamine-Induced Vertical Activity}

Intracerebral administration of baclofen did not have a signficant effect on vertical activity as compared to that of ACSF in saline-treated rats habituated to the photocell chamber for $1 \mathrm{~h}$ prior to injection (Figure 2). Intra-VTA infusion of baclofen (75 ng/side) completely blocked amphetamine-stimulated vertical activity as compared to that of intra-VTA ACSF in amphetamine-treated rats $(P<0.001)$ (Figure 2a). Both intra-NA (Figure 2b) and intra-SN (Figure 2c) infusion of baclofen attenuated amphetamine-induced vertical activity as compared to that of ACSF in amphetamine-treated rats $(P<0.01$, for NA and $P<0.05$ for $\mathrm{SN})$. Neither intra-mPFC or intra-CPu infusion 
a

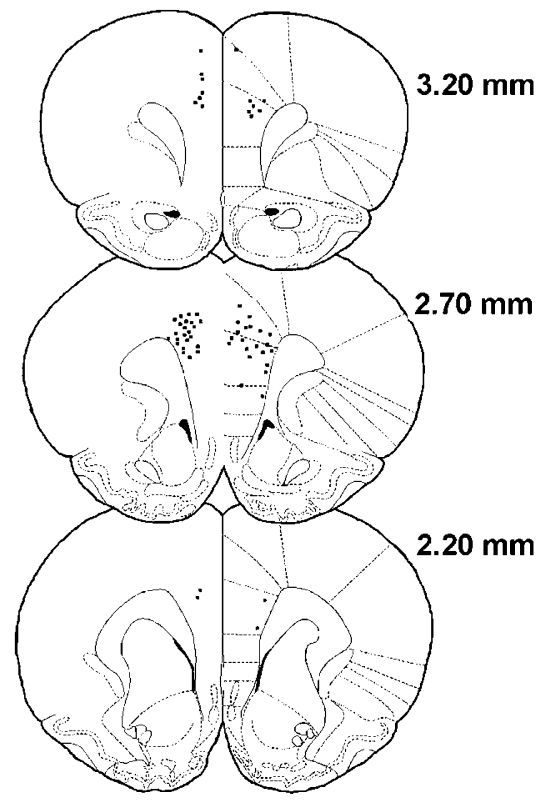

b

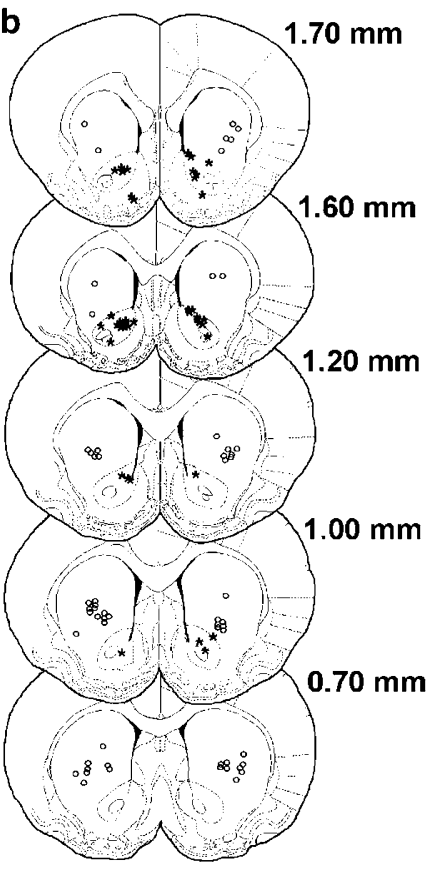

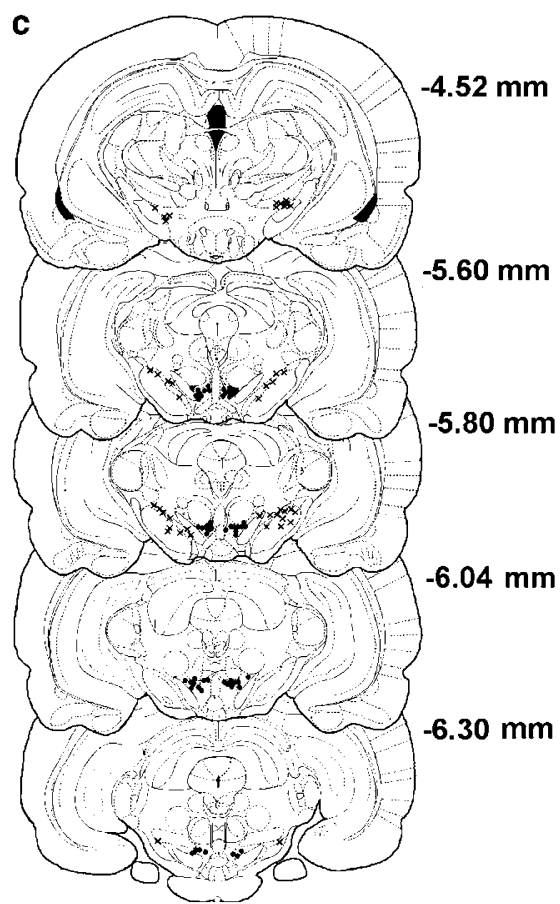

Figure I Location of microinjection cannula tips in coronal sections based on the atlas of Paxinos and Watson (1986). Numbers indicate the distance from bregma in the anteroposterior plane. (a) mPFC (b) $\mathrm{CPu}(\mathrm{O})$ and NA (*); (c) VTA (O) and SN (x).

of baclofen had any effect on amphetamine-induced vertical activity as compared to that of ACSF in amphetaminetreated rats (data not shown). In contrast, infusion of baclofen into the VTA, NA, SN, mPFC, or CPu did not affect amphetamine-induced total distance traveled as compared to that of ACSF in amphetamine-treated rats (data not shown).

Intra-VTA, Intra-NA, and Intra-SN Infusion of Baclofen Decreased Amphetamine-Induced Neuropeptide Gene Expression in the Striatum

Two-way ANOVA of the effects of intra-VTA infusion of baclofen on amphetamine-induced neuropeptide mRNA expression in the $\mathrm{CPu}$ and NA core and shell (Table 1) revealed that treatment 1 (intracerebral infusion) and treatment 2 (intraperitoneal injection) had a significant main effect and the interaction between the two treatments was significant in all cases. LSM comparisons indicated that the intra-VTA infusion of baclofen had no effect on gene expression in saline-treated rats but it decreased amphetamine-induced increases in PPD, PPT, PPE, and SGII mRNA in the $\mathrm{CPu}$. In the NA shell, intra-VTA infusion of baclofen decreased amphetamine-induced PPD and SGII mRNA without altering basal levels of mRNA in saline-treated rats. In the NA core, intra-VTA baclofen decreased amphetamine-induced PPD, PPE, and SGII mRNA levels but had no effect on basal gene expression in saline-treated rats. Figure 3 illustrates representative, digitized micrographs of the effect of baclofen infusion into the VTA on PPD, PPT, PPE, and SGII mRNA expression in the striatum.

Two-way ANOVA of the effects of intra-NA infusion of baclofen on amphetamine-induced neuropeptide mRNA expression in the striatum (Table 2 ) revealed that treatment 1 (intracerebral infusion) and treatment 2 (intraperitoneal injection) had a significant main effect and the interaction between the two treatments was significant in all cases. LSM comparisons indicated that the intra-NA infusion of baclofen decreased amphetamine-induced increases in PPD, PPT, PPE, and SGII mRNA in the CPu, NA shell, and NA core without altering basal levels in saline-treated rats. Figure 4 illustrates representative, digitized micrographs of the effect of intra-NA baclofen infusion on PPD, PPT, PPE, and SGII mRNA expression in the striatum. Note that the cannula tracts are either not visible or minimally affect the pattern of gene expression because the sections are adjacent to the center of the injection sites.

Two-way ANOVA of the effects of intra-SN infusion of baclofen on amphetamine-induced neuropeptide mRNA expression in the striatum (Table 3 ) revealed that treatment 1 (intracerebral infusion) and treatment 2 (intraperitoneal injection) had a significant main effect and the interaction between the two treatments was significant in all cases. The intra-SN infusion of baclofen had no effect on mRNA levels in saline-treated animals. LSM comparisons indicated that intra-SN infusion of baclofen decreased amphetamineinduced increases of all mRNAs in the $\mathrm{CPu}, \mathrm{NA}$ shell, and NA core. For PPE, baclofen significantly decreased expression in the $\mathrm{CPu}$ and NA core but not in the NA shell.

\section{DISCUSSION}

The major finding of this study is that $\mathrm{GABA}_{\mathrm{B}}$ receptor activation in the VTA, NA, and SN decreased amphetamineinduced vertical activity and striatal gene expression (summarized in Table 4). Further, baclofen had no effect on amphetamine-induced vertical or horizontal activity when infused into the $\mathrm{CPu}$ or mPFC nor did it affect total 
a
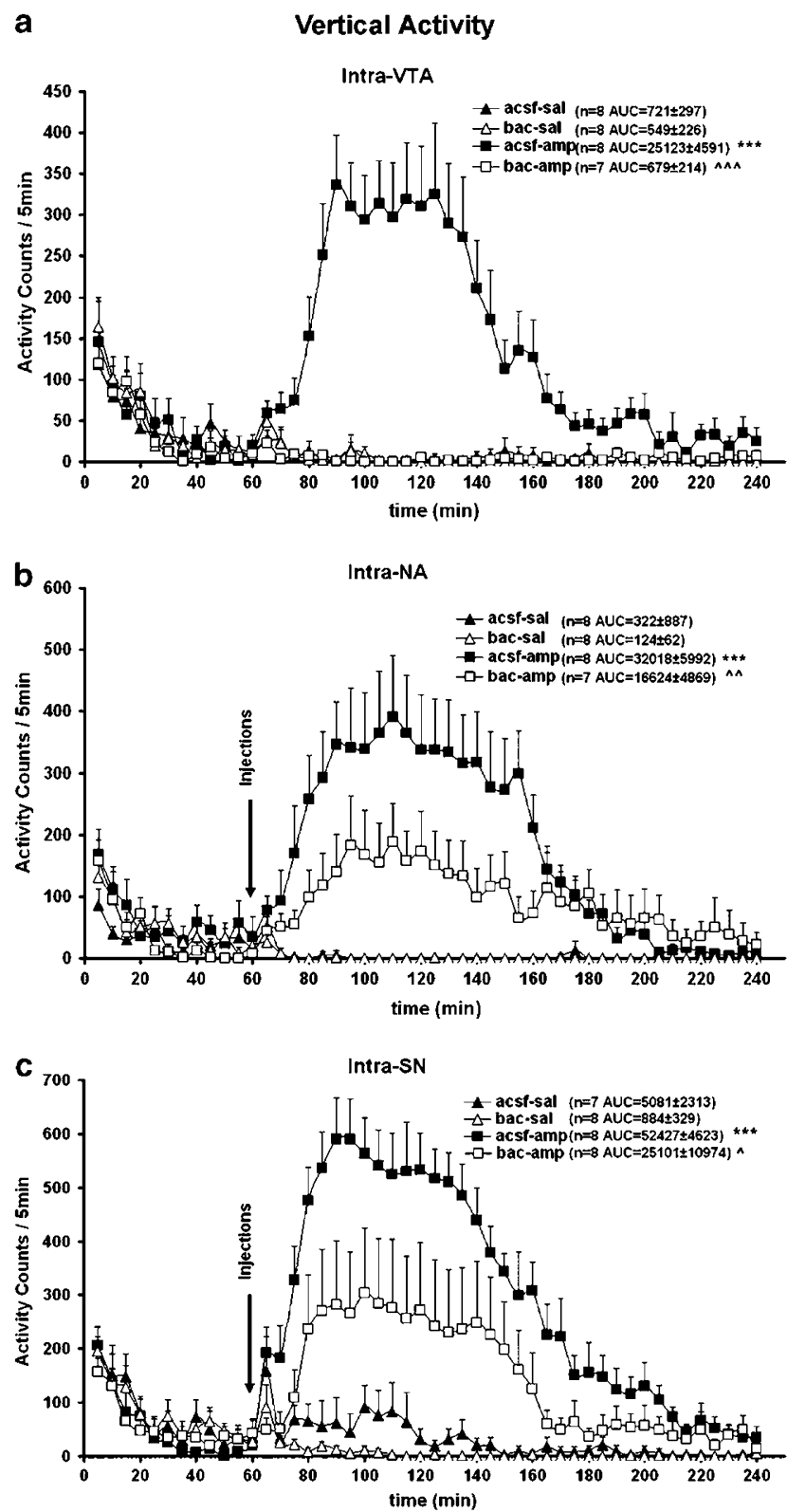

Figure 2 The effects of (a) intra-VTA, (b) intra-NA, and (c) intra-SN infusion of baclofen (bac, $75 \mathrm{ng} / \mathrm{side}$ ) or ACSF on amphetamine (amp, $2.5 \mathrm{mg} / \mathrm{kg}$, i.p.)-induced vertical activity in rats. The activity and AUC values are expressed as mean $+S E M$. ****P<0.00I vs ACSF + saline; $\wedge \wedge \wedge P<0.001$ vs ACSF + amphetamine; $\wedge \wedge p<0.01$ vs ACSF + amphetamine; $\wedge p<0.05$ vs ACSF + amphetamine.

distance traveled after infusion into any of the brain areas investigated. By identifying brain areas that mediate baclofen's effects, these results extend our previous study (Zhou et al, 2004) that demonstrated similar effects of systemically administered baclofen on amphetamine-induced vertical activity and striatal gene expression.

\section{Effects of Intracerebral Baclofen on Amphetamine-Induced Behavior}

In addition to mediating amphetamine-induced horizontal activity, the basal ganglia mediate amphetamine-induced vertical activity as part of a rat's exploratory repertoire (Creese and Iversen, 1972; Kelly et al, 1975; Fink and Smith, 1980; Koob et al, 1981; Clarke et al, 1988). However, GABA ${ }_{B}$ receptor stimulation in the VTA, SN, and NA selectively decreased amphetamine-induced vertical activity, a measure of exploratory rearing, without altering total distance traveled, a measure of horizontal locomotion. There was a difference in the regional sensitivity of baclofen's effects: intra-VTA infusion of baclofen completely blocked, whereas intra-NA or intra-SN infusion of baclofen attenuated, amphetamine-induced rearing. Interestingly, intra-VTA infusion of cholecystokinin (CCK) also significantly blocked amphetamine-induced rearing but not amphetamine-induced forward locomotion in a previous study (Schneider et al, 1983).

It is possible that diffusion from SN to the VTA accounts for the reduced effectiveness of baclofen in the SN. This possibility is made less likely, however, by the fact that baclofen was equally effective when infused into the lateral SN as in the medial SN. Similarly, baclofen's effects in the NA are unlikely to be explained by diffusion to the overlying $\mathrm{CPu}$ because intra- $\mathrm{CPu}$ baclofen did not affect behavior at all. Even though the intra- $\mathrm{CPu}$ infusion coordinates were more lateral and caudal than the NA coordinates, most of the $\mathrm{CPu}$ infusion sites were mapped to sections that contained NA sites (Figure 1). Therefore, the difference in the effect of intra-CPu and NA infusions indicates that there was little diffusion from one site to the other. Thus, while these results indicate that $\mathrm{GABA}_{B}$ receptors in the VTA are critical mediators of amphetamine-induced rearing, $G_{A B A}$ receptors in the SN and NA also appear to contribute, perhaps by altering trans-synaptic activity in the motive circuit.

The mechanisms underlying baclofen's selective effects on amphetamine-induced rearing may include a reduction of amphetamine-evoked extracellular dopamine levels in the striatum that allows locomotion to proceed but more complex exploratory behaviors to be suppressed (Zhou et al, 2004). In support of the regional differences in baclofen's effectiveness, perfusion of baclofen into the SN decreased basal and nomifensine-induced extracellular dopamine levels in the $\mathrm{SN}$ and $\mathrm{CPu}$, but infusion into the $\mathrm{CPu}$ did not decrease striatal dopamine levels (Westerink et al, 1992; Santiago et al, 1993; Balon et al, 2002). $\mathrm{GABA}_{\mathrm{B}}$ receptors are expressed by striatonigral, striatopallidal, and glutamatergic afferents as well as by dopamine and GABA neurons in the SN and VTA (Sugita et al, 1992; Charara et al, 2000; Boyes and Bolam, 2003). However, the amphetaminesuppressing effect of baclofen in the ventral mesencephalon is most consistent with a direct action on dopamine neurons. Baclofen decreases burst firing of dopamine neurons that is associated with phasic dopamine release in the SN and VTA (Engberg et al, 1993; Erhardt et al, 2002). How can baclofen decrease amphetamine-induced dopamine release in the striatum by decreasing burst firing of dopamine neurons? Amphetamine triggers dopamine release by reversing the dopamine transporter. However, we have demonstrated by in vivo microdialysis that approximately $40-50 \%$ of the acute amphetamine-induced increase in extracellular dopamine levels in the striatum is calcium and tetrodotoxin-dependent (Gray et al, 1999; Paredes et al, 2001), suggesting that dopamine neuronal firing contributes 
Table I Intra-VTA Baclofen Infusion Decreases Amphetamine-Induced Striatal Neuropeptide Gene Expression

\begin{tabular}{|c|c|c|c|c|c|}
\hline Region & Group & PPD & PPT & PPE & SGII \\
\hline \multirow[t]{4}{*}{$\mathrm{CPu}$} & $\mathrm{A} / \mathrm{S}$ & $570 \pm 30$ & $3582 \pm 144$ & $4605 \pm 147$ & $608 \pm 35$ \\
\hline & $\mathrm{B} / \mathrm{S}$ & $672 \pm 80$ & $3921 \pm 158$ & $4297 \pm 155$ & $570 \pm 59$ \\
\hline & A/AM & $1022 \pm 53^{* * * * * *}$ & $4696 \pm 166 * * *$ & $5363 \pm 268^{* * *}$ & $927 \pm 47 * * * * *$ \\
\hline & B/AM & $658 \pm 34^{\wedge \wedge \wedge}$ & $3509 \pm 76^{\wedge \wedge \wedge}$ & $4283 \pm 138^{\wedge \wedge \wedge}$ & $540 \pm 27^{\wedge \wedge \wedge}$ \\
\hline \multirow{3}{*}{ NA shell } & $\mathrm{B} / \mathrm{S}$ & $515 \pm 26$ & $1148 \pm 50$ & $711 \pm 28$ & $1386 \pm 77$ \\
\hline & AVAM & $640 \pm 23 * * *$ & $|27| \pm 48 * * *$ & $866 \pm 36 * *$ & $1735 \pm 57$ ***** \\
\hline & $\mathrm{B} / \mathrm{AM}$ & $513 \pm 30^{\wedge}$ & $1184 \pm 46$ & $809 \pm 32$ & $1290 \pm 44^{\wedge} \wedge \wedge$ \\
\hline NA core & A/S & $1104 \pm 98$ & $1640 \pm 79$ & $2693 \pm 98$ & $2116 \pm 118$ \\
\hline
\end{tabular}

Integrated density values are expressed as mean $\pm \mathrm{SEM}$ in thousands.

$\mathrm{A} / \mathrm{S}=\mathrm{ACSF}+$ saline $(n=8) ; \mathrm{B} / \mathrm{S}=$ baclofen+saline $(n=8) ; \mathrm{A} / \mathrm{AM}=\mathrm{ACSF}+$ amphetamine $(n=8) ; \mathrm{B} / \mathrm{AM}=$ baclofen+amphetamine $(n=8)$.

$* P<0.05$ vs ACSF+saline; $* * * 0.01$ vs $A C S F+$ saline; $* * * * P<0.00$ I vs $A C S F+$ saline

$\wedge P<0.05$ vs ACSF+amphetamine; $\wedge \wedge P<0.05$ vs ACSF+amphetamine; ${ }^{\wedge} \wedge p<0.001$ vs ACSF+amphetamine.

Table 2 Intra-NA Baclofen Infusion Decreases Amphetamine-Induced Striatal Neuropeptide Gene Expression

\begin{tabular}{|c|c|c|c|c|c|}
\hline Region & Group & PPD & PPT & PPE & SGII \\
\hline \multirow[t]{3}{*}{$\mathrm{CPu}$} & A/S & $330 \pm 17$ & $1325 \pm 16 \mid$ & $2803 \pm 179$ & $588 \pm 28$ \\
\hline & $B / S$ & $293 \pm 13$ & $|48| \pm 133$ & $2500 \pm 109$ & $567 \pm 24$ \\
\hline & $\mathrm{B} / \mathrm{AM}$ & $266 \pm 9 \wedge \wedge \wedge$ & $1822 \pm 207^{\wedge \wedge \wedge}$ & $2977 \pm 146^{\wedge \wedge \wedge}$ & $537 \pm 29 \wedge \wedge \wedge$ \\
\hline \multirow{2}{*}{ NA shell } & A/AM & $527 \pm 18 * * * *$ & $806 \pm 55 * * *$ & $606 \pm 35 * * * *$ & $716 \pm 29 * * * * *$ \\
\hline & $\mathrm{B} / \mathrm{AM}$ & $328 \pm 8^{\wedge \wedge \wedge}$ & $597 \pm 26^{\wedge \wedge}$ & $427 \pm 18^{\wedge \wedge \wedge}$ & $454 \pm 22^{\wedge \wedge \wedge}$ \\
\hline \multirow[t]{2}{*}{ NA core } & A/S & $615 \pm 36$ & $1497 \pm 99$ & $2201 \pm 102$ & $610 \pm 36$ \\
\hline & $\mathrm{B} / \mathrm{S}$ & $577 \pm 24$ & $1559 \pm 47$ & $2066 \pm 56$ & $588 \pm 16$ \\
\hline
\end{tabular}

Integrated density values are expressed in mean \pm SEM in thousands.

$\mathrm{A} / \mathrm{S}=\mathrm{ACSF}+$ saline $(n=7) ; \mathrm{B} / \mathrm{S}=$ baclofen+saline $(n=8) ; \operatorname{A} / \mathrm{AM}=\operatorname{ACSF}+$ amphetamine $(n=8) ; \mathrm{B} / \mathrm{AM}=$ baclofen+amphetamine $(n=8)$.

$* P<0.05$ vs ACSF+saline; *** $P<0.01$ vs $A C S F+$ saline; $* * * * P<0.001$ vs $A C S F+$ saline

$\wedge P<0.05$ vs ACSF+amphetamine; $\wedge \wedge P<0.01$ vS ACSF+amphetamine; $\wedge \wedge \wedge P<0.00$ I vs ACSF+amphetamine.

to amphetamine-induced dopamine release in vivo. This line of reasoning is consistent with the fact that systemic baclofen decreases cocaine or amphetamine-induced dopamine levels in the striatum by $\sim 40-50 \%$ (Fadda et al, 2003; Zhou et al, 2004). Less is known about the cellular distribution of $\mathrm{GABA}_{\mathrm{B}}$ receptors and their coupling in the dorsal and ventral striatum of rodents, but Charara et al (2000) demonstrated $\mathrm{GABA}_{\mathrm{B}}$ immunoreactivity in striatal boutons that make asymmetric contacts with labeled and unlabeled dendritic spines. The presynaptic localization in glutamatergic afferents is consistent with electrophysiological evidence that the predominant effect of baclofen in the striatum is to decrease excitatory synaptic input (Nisenbaum et al, 1993). Thus, although the neural substrates that mediate amphetamine-induced rearing are incompletely understood, this study suggests that pre- and postsynaptic $\mathrm{GABA}_{\mathrm{B}}$ receptors in the VTA, $\mathrm{SN}$, and NA are differentially involved. 


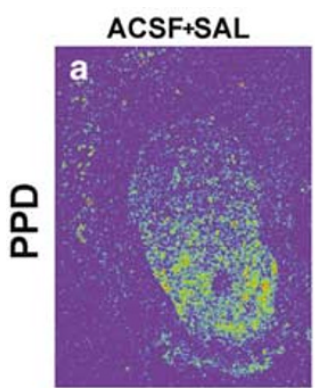

\section{$B A C+S A L$}
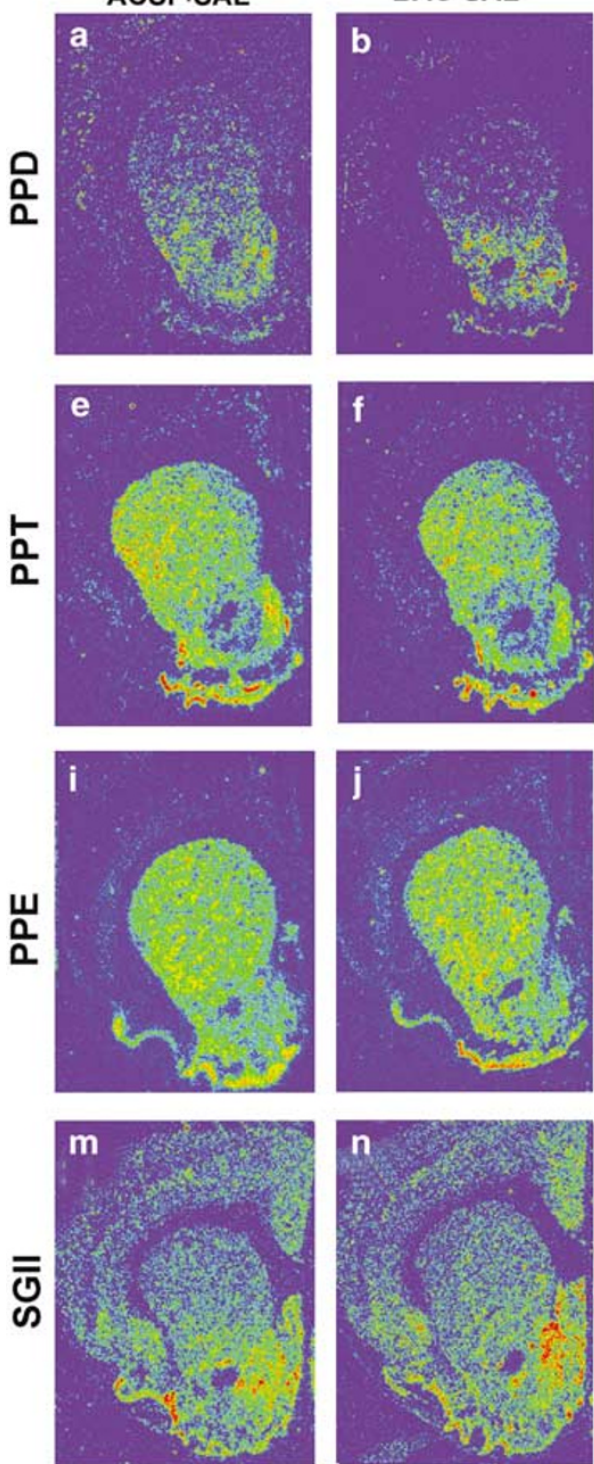

ACSF+AMP
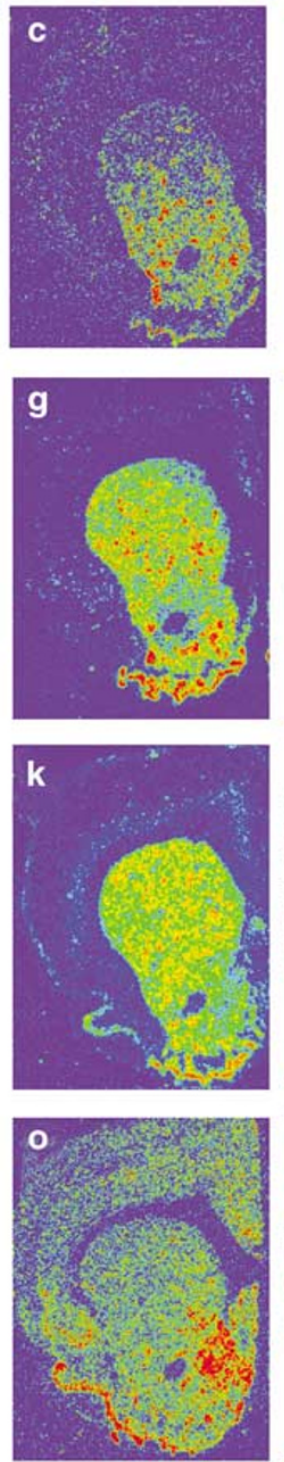

BAC+AMP
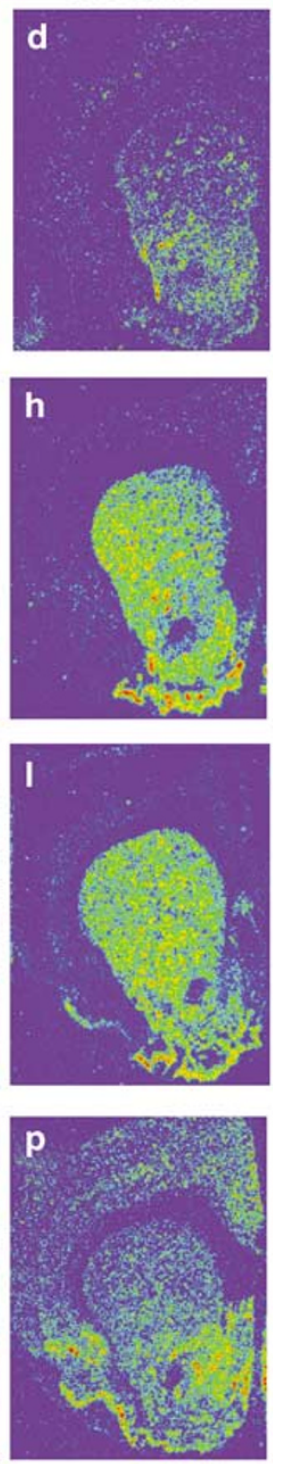

Figure 3 Representative digitized photomicrographs illustrate the effects of intra-VTA infusion of baclofen (bac, 75 ng/side) or ACSF on amphetamine (amp, $2.5 \mathrm{mg} / \mathrm{kg}$, i.p.)-induced (a-d) PPD, (e-h) PPT, (i-l) PPE, and (m-p) SGll mRNA expression in the striatum.

In contrast to the effects of baclofen in VTA, SN, and NA, our results indicate that the stimulatory effect of amphetamine on behavior is not mediated through $\mathrm{GABA}_{\mathrm{B}}$ receptors in the $\mathrm{mPFC}$ or $\mathrm{CPu}$. Owing to the functional heterogeneity of the striatum, it is possible that even the large volume of baclofen infused into the $\mathrm{CPu}$ did not reach the areas that mediate locomotion or rearing. Indeed, Dickson et al (1994) reported that amphetamine infusion into the middle ventromedial region $(\mathrm{AP}+2.0 \mathrm{~mm}, \mathrm{ML}+2.0 \mathrm{~mm}$, and DV $-7.0 \mathrm{~mm}$ ) had stimulatory effects on locomotion and rearing but had no effect on oral stereotypy, whereas an injection of amphetamine anterior or posterior in the striatum had no effect on locomotion. However, in contrast to the lack of effect of baclofen, infusions of muscarinic and mGluR ligands into this area of the $\mathrm{CPu}$ had profound effects on amphetamine-induced behavioral activity (Wang and McGinty, 1996, 1997). Thus, the lack of effect of intra-
$\mathrm{CPu}$ baclofen is more likely because $\mathrm{CPu} \mathrm{GABA}_{\mathrm{B}}$ receptors are not involved in acute amphetamine-induced behaviors than to the heterogeneity of the striatum. Similarly, $\mathrm{GABA}_{\mathrm{B}}$ receptors in the $\mathrm{MPFC}$ appear not to be involved in the motor stimulatory effects of acute amphetamine although intra-mPFC baclofen decreases nomifensine-induced extracellular dopamine levels in PFC (Santiago et al, 1993). Similarly, selective quinolinic acid-induced lesions of the prelimbic cortex ( $\mathrm{Cg} 3)$, which only destroy intrinsic neurons, did not affect locomotion and rearing responses induced by amphetamine (Tzschentke and Schmidt, 1998). Once again, however, the selectivity of the neurotransmitter system and the specific circuitry may be key factors because the intra-PFC infusion of the alphal-adrenergic receptor antagonist, prazocin, blocks amphetamine-induced locomotor activity and mesoaccumbens DA release (Darracq et al, 1998; Ventura et al, 2003). 

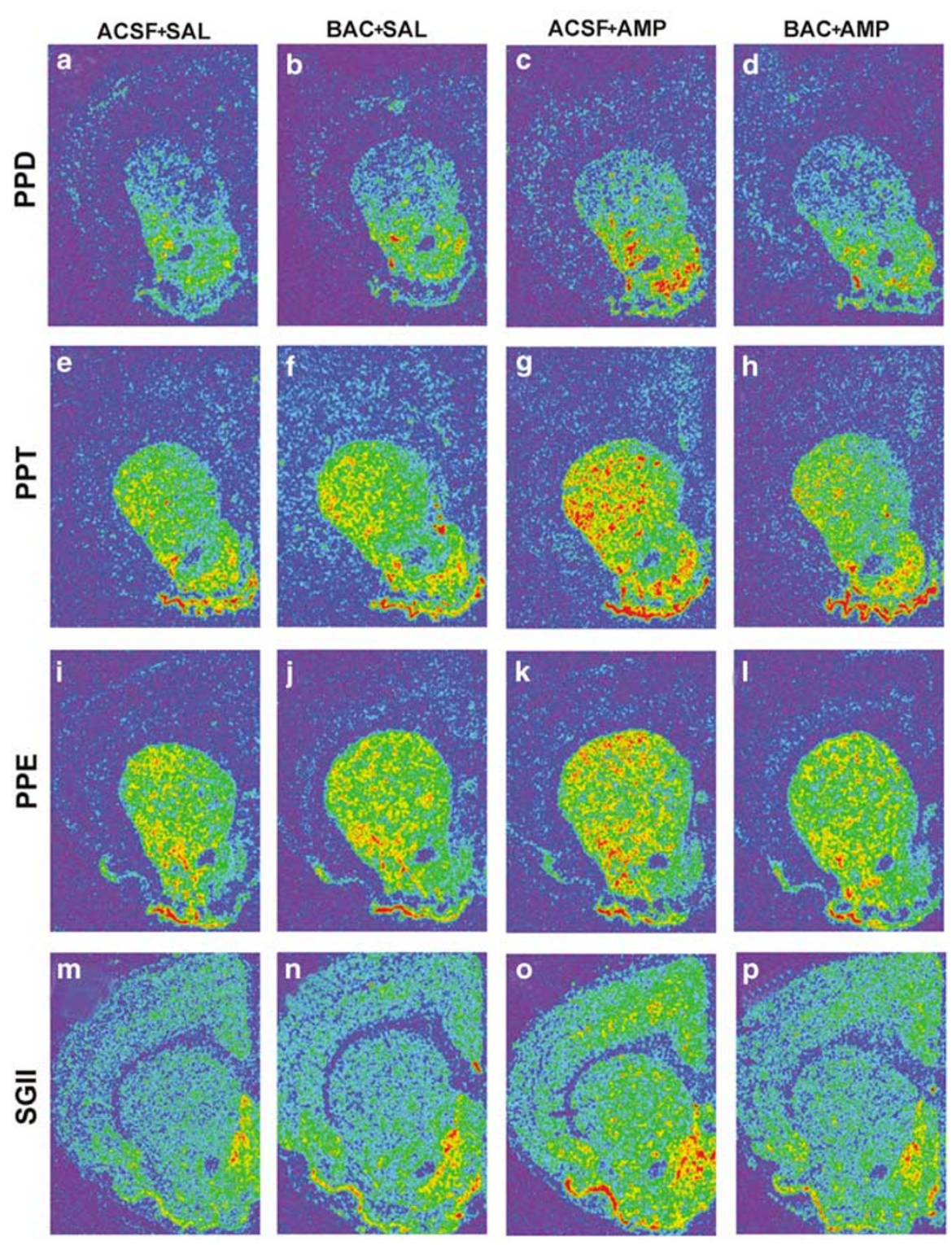

Figure 4 Representative digitized photomicrographs illustrate the effects of intra-NA infusion of baclofen (bac, $75 \mathrm{ng} / \mathrm{side}$ ) or ACSF on amphetamine (amp, $2.5 \mathrm{mg} / \mathrm{kg}$, i.p.)-induced (a-d) PPD, (e-h) PPT, (i-l) PPE, and (m-p) SGll mRNA expression in the striatum.

\section{Baclofen Effects on Amphetamine-Induced Neuropeptide Gene Expression}

With few exceptions, infusion of baclofen into the VTA, NA, or SN decreased amphetamine-induced neuropeptide mRNA expression in the $\mathrm{CPu}$ and/or the NA to similar extents. In those cases in which the baclofen effect did not reach significance (PPT in NA shell and core, PPE in NA shell after VTA infusion and PPE in shell after SN infusion), the initial AMPH-induce increase was not robust, possibly due to variability in sampling or section level. Medium spiny neuropeptide genes are not thought to mediate the acute effects of amphetamine, but are triggered as part of the initial cascade of neuroadaptive changes induced by psychostimulants. A strong and/or repeated exposure to drugs is required to alter the mRNA levels of striatal peptides (Wang and McGinty, 1995b; Hanson et al, 2002). Therefore, a decrease in dopamine stimulus strength, as reflected in reduced vertical activity after SN and NA baclofen infusions, may be as effective in reducing gene expression as complete suppression by VTA infusions. In fact, we have found previously that acute behavioral activity is not $100 \%$ correlated to changes in striatal gene expression. For example, ionotropic glutamate receptor antagonists had no effect on acute amphetamine-induced behavioral activity but completely suppressed amphetamine-induced striatal neuropeptide gene expression (Wang et al, 1994a, b). This dissociation is understandable if one considers that glutamate neurotransmission plays a greater role in behavioral sensitization induced by repeated stimulant administration than in behaviors induced by acute stimulant administration (Karler et al, 1990; Vanderschuren and Kalivas, 2000).

The question remains as to why baclofen infusions into the VTA or NA would affect CPu gene expression or infusion into the $\mathrm{SN}$ would affect NA gene expression. One 
Table 3 Intra-SN Baclofen Infusion Decreases Amphetamine-Induced Striatal Neuropeptide Gene Expression

\begin{tabular}{|c|c|c|c|c|c|}
\hline Region & Group & PPD & PPT & PPE & SGII \\
\hline \multirow[t]{4}{*}{$\mathrm{CPu}$} & $\mathrm{A} / \mathrm{S}$ & $362 \pm 131$ & $2523 \pm 111$ & $4008 \pm 25$ & $265 \pm 17$ \\
\hline & $\mathrm{B} / \mathrm{S}$ & $376 \pm 16$ & $2724 \pm 130$ & $4463 \pm 26$ & $310 \pm 16$ \\
\hline & A/AM & $547 \pm 22 * * * * *$ & $3808 \pm 180 * * * *$ & $5728 \pm 30$ ******** & $480 \pm 36 * *$ \\
\hline & B/AM & $429 \pm 13^{\wedge \wedge \wedge}$ & $2932 \pm|2|^{\wedge \wedge \wedge}$ & $400 I \pm 24^{\wedge \wedge \wedge}$ & $371 \pm 16^{\wedge}$ \\
\hline & $\mathrm{B} / \mathrm{S}$ & $405 \pm 21$ & $678 \pm 53$ & $543 \pm 19$ & $329 \pm 16$ \\
\hline & A/AM & $521 \pm 19 * * * *$ & 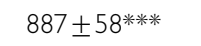 & $619 \pm 27 *$ & $559 \pm 22 *$ \\
\hline & B/AM & $384 \pm 15^{\wedge \wedge}$ & $734 \pm 25^{\wedge \wedge}$ & $597 \pm 26$ & $398 \pm 19^{\wedge}$ \\
\hline NA core & A/S & $624 \pm 25$ & $883 \pm 75$ & $2688 \pm 166$ & $403 \pm 22$ \\
\hline
\end{tabular}

Integrated density values are expressed in mean \pm SEM in thousands.

$\mathrm{A} / \mathrm{S}=\mathrm{ACSF}+$ saline $(n=7) ; \mathrm{B} / \mathrm{S}=$ baclofen+saline $(n=8) ; \mathrm{A} / \mathrm{AM}=\operatorname{ACSF}+$ amphetamine $(n=8) ; \mathrm{B} / \mathrm{AM}=$ baclofen+amphetamine $(n=7)$.

$* P<0.05$ vs ACSF+saline; *** $P<0.01$ vs ACSF+saline; **** $P<0.00$ I vs ACSF+saline.

$\wedge p<0.05$ vs ACSF+amphetamine; $\wedge \wedge p<0.01$ vs ACSF+amphetamine; $\wedge \wedge \wedge p<0.00$ I vs ACSF+amphetamine.

Table 4 Effects of Intracranial Baclofen Infusion on AmphetamineInduced Behaviors and Striatal Neuropeptide Gene Expression

\begin{tabular}{lcccccc}
\hline & VTA & NA & SN & CPu & mPFC \\
\hline Vertical activity & $\Downarrow$ & $\downarrow$ & $\downarrow$ & $\leftrightarrow$ & $\leftrightarrow$ \\
Total distance traveled & $\leftrightarrow$ & $\leftrightarrow$ & $\leftrightarrow$ & $\leftrightarrow$ & $\leftrightarrow$ \\
Neuropeptide gene expression & $\downarrow$ & $\downarrow$ & $\downarrow$ & ND & ND \\
\hline
\end{tabular}

$\Downarrow$ baclofen+amphetamine vs ACSF+amphetamine.

$\downarrow$ baclofen+amphetamine vs ACSF+amphetamine.

$\leftrightarrow$ No change, ND not done.

possible explanation is that these interactions may be mediated by the often overlooked, direct GABAergic projection from the NA core to the $\mathrm{SN}$ and the dopaminergic projection from the VTA to ventromedial $\mathrm{CPu}$ (Nauta et al, 1978; Loughlin and Fallon, 1982; Gerfen et al, 1987; Heimer et al, 1991; Zahm and Heimer, 1993). These convergent connections that allow information to flow between dorsal and ventral striatal circuitries of rodents may be similar to those more recently described in the primate as 'spirals' (Haber et al, 2000). By way of this convergence, $\mathrm{GABA}_{\mathrm{B}}$ receptors have several presynaptic and postsynaptic targets in VTA, SN, and NA through which they can exert their effects on amphetamine-induced behavior and striatal neuropeptide gene expression.

\section{CONCLUSION}

The present study demonstrated that interactions between the VTA, NA, and SN mediate baclofen's ability to decrease amphetamine-induced rearing and neuropeptide gene expression in the striatum. Thus, stimulation of $G_{A B A}$ receptors in multiple sites in the motive circuit contributes to the initial behavioral and genomic responses to amphetamine.

\section{ACKNOWLEDGEMENTS}

We thank Ms Lan Jin for her technical assistance. This work was supported by DA03982.

\section{REFERENCES}

Anderson JJ, Kuo S, Chase TN, Engber TM (1994). Dopamine D1 receptor-stimulated release of acetylcholine in rat striatum is mediated indirectly by activation of striatal neurokinin 1 receptors. J Pharmacol Exp Ther 269: 1144-1151.

Balon N, Kriem B, Weiss M, Rostain JC (2002). GABA ${ }_{A}$ receptors in the pars compacta and $G A B A B$ receptors in the pars reticulata of rat substantia nigra modulate striatal dopamine release. Neurochem Res 27: 373-379.

Bowery NG (1993). GABA $\mathrm{B}_{\mathrm{B}}$ receptor pharmacology. Annu Rev Pharmacol Toxicol 33: 109-147.

Boyes J, Bolam JP (2003). The subcellular localization of GABA(B) receptor subunits in the rat substantia nigra. Eur J Neurosci 18: 3279-3293.

Brebner K, Childress AR, Roberts DC (2002). A potential role for GABA(B) agonists in the treatment of psychostimulant addiction. Alcohol Alcohol 37: 478-484.

Brebner K, Phelan R, Roberts DC (2000). Effect of baclofen on cocaine self-administration in rats reinforced under fixed-ratio 1 and progressive-ratio schedules. Psychopharmacology (Berlin) 148: 314-321.

Campbell UC, Lac ST, Carroll ME (1999). Effects of baclofen on maintenance and reinstatement of intravenous cocaine selfadministration in rats. Psychopharmacology (Berlin) 143: 209-214. 
Charara A, Heilman C, Levey AI, Smith Y (2000). Pre- and postsynaptic localization of $\mathrm{GABA}_{\mathrm{B}}$ receptors in the basal ganglia of monkeys. Neuroscience 95: 127-140.

Chu DC, Albin RL, Young AB, Penney JB (1990). Distribution and kinetics of GABAB binding sites in rat central nervous system: a quantitative autoradiographic study. Neuroscience 34: 341-357.

Clarke PB, Jakubovic A, Fibiger HC (1988). Anatomical analysis of the involvement of mesolimbocortical dopamine in the locomotor stimulant actions of d-amphetamine and apomorphine. Psychopharmacology (Berlin) 96: 511-520.

Creese I, Iversen SD (1972). Amphetamine response in rat after dopamine neurone destruction. Nat New Biol 238: 247-248.

Darracq L, Blanc G, Glowinski J, Tassin JP (1998). Importance of the noradrenaline-dopamine coupling in the locomotor activating effects of D-amphetamine. J Neurosci 18: 2729-2739.

Dickson PR, Lang CG, Hinton SC, Kelley AE (1994). Oral stereotypy induced by amphetamine microinjection into striatum: an anatomical mapping study. Neuroscience 61: 81-91.

Engberg G, Kling-Petersen T, Nissbrandt H (1993). GABABreceptor activation alters the firing pattern of dopamine neurons in the rat substantia nigra. Synapse 15: 229-238.

Erhardt S, Mathe JM, Chergui K, Engberg G, Svenson TH (2002). $\mathrm{GABA}_{\mathrm{B}}$ receptor-mediated modulation of the firing pattern of ventral tegmental area dopamine neurons in vivo. NS Arch Pharmacol 365: 173-180.

Fadda P, Scherma M, Fresu A, Collu M, Fratta W (2003). Baclofen antagonizes nicotine-, cocaine-, and morphine-induced dopamine release in the nucleus accumbens of the rat. Synapse 50: $1-6$.

Fink JS, Smith GP (1980). Mesolimbic and mesocortical dopaminergic neurons are necessary for normal exploratory behavior in rats. Neurosci Lett 17: 61-65.

Gerfen CR, Herkenham M, Thibault T (1987). The neostriatal mosaic II: patch- and matrix-directed mesostriatal dopaminergic and non-dopaminergic systems. J Neurosci 7: 3915-3934.

Gonzalez-Nicolini V, McGinty JF (2002). Gene expression profile from the striatum of amphetamine-treated rats: a cDNA array and in situ hybridization histochemical study. Brain Res Gene Expression Patterns 1: 193-198.

Gray AM, Rawls SM, Shippenberg TS, McGinty JF (1999). The kappa-opioid agonist, U-69593, decreases acute amphetamineevoked behaviors and calcium-dependent dialysate levels of dopamine and glutamate in the ventral striatum. J Neurochem 73: $1066-1074$.

Guzman RG, Kendrick KM, Emson PC (1993). Effect of substance P on acetylcholine and dopamine release in the rat striatum: a microdialysis study. Brain Res 622: 147-154.

Haber SN, Fudge JL, McFarland NR (2000). Striatonigrostriatal pathways in primates form an ascending spiral from the shell to the dorsolateral striatum. J Neurosci 20: 2369-2382.

Hanson GR, Bush L, Keefe KA, Alburges ME (2002). Distinct responses of basal ganglia substance $\mathrm{P}$ systems to low and high doses of methamphetamine. J Neurochem 82: 1171-1178.

Heijna MH, Padt M, Hogenboom F, Portoghese PS, Mulder AH, Schoffelmeer AN (1990). Opioid receptor-mediated inhibition of dopamine and acetylcholine release from slices of rat nucleus accumbens, olfactory tubercle and frontal cortex. Eur $J$ Pharmacol 181: 267-278.

Heimer L, Zahm DS, Churchill L, Kalivas PW, Wohltmann C (1991). Specificity in the projection patterns of accumbal core and shell in the rat. Neuroscience 41: 89-125.

Huttner WB, Gerdes HH, Rosa P (1991). The granin (chromogranin/secretogranin) family. Trends Biochem Sci 16: 27-30.

Kalivas PW, Duffy P, Eberhardt H (1990). Modulation of A10 dopamine neurons by gamma-aminobutyric acid agonists. J Pharmacol Exp Ther 253: 858-866.
Kalivas PW, Stewart J (1991). Dopamine transmission in the initiation and expression of drug- and stress-induced sensitization of motor activity. Brain Res Rev 16: 223-244.

Karler R, Chaudhry IA, Calder LD, Turkanis SA (1990). Amphetamine behavioral sensitization and the excitatory amino acids. Brain Res 537: 76-82.

Kelly PH, Seviour PW, Iversen SD (1975). Amphetamine and apomorphine responses in the rat following 6-OHDA lesions of the nucleus accumbens septi and corpus striatum. Brain Res 94: 507-522.

Koob GF, Stinus L, Le Moal M (1981). Hyperactivity and hypoactivity produced by lesions to the mesolimbic dopamine system. Behav Brain Res 3: 341-359.

Lopez-Bendito G, Shigemoto R, Kulik A, Paulsen O, Fairen A, Lujan R (2002). Expression and distribution of metabotropic GABA receptor subtypes GABABR1 and GABABR2 during rat neocortical development. Eur J Neurosci 15: 1766-1778.

Loughlin SE, Fallon JH (1982). Mesostriatal projections from ventral tegmentum and dorsal raphe: cells project ipsilaterally or contralaterally but not bilaterally. Neurosci Lett 32: $11-16$.

Misgeld U, Bijak M, Jarolimek W (1995). A physiological role for GABAB receptors and the effects of baclofen in the mammalian central nervous system. Prog Neurobiol 46: 423-462.

Nauta WHJ, Smith GP, Faull RLM, Domesick VB (1978). Efferent connections and nigral afferents of the nucleus accumbens septi in the rat. Neuroscience 3: 385-401.

Nisenbaum ES, Berger TW, Grace AA (1993). Depression of glutamatergic and GABAergic synaptic responses in striatal spiny neurons by stimulation of presynaptic GABAB receptors. Synapse 14: 221-242.

Paredes D, Catlow B, McGinty JF (2001). Amphetamineinduced increase in dopamine levels in dorsal striatum in vivo is partially sodium-dependent. Soc Neurosci Abstr 744: 11.

Paxinos G, Watson C (1986). The Rat Brain in Stereotaxic Coordinates. Academic Press: San Diego.

Rawls SM, McGinty JF (2000). Delta opioid receptors regulate calcium-dependent, amphetamine-evoked glutamate levels in the rat striatum: an in vivo microdialysis study. Brain Res 861: 296-304.

Roberts DC, Andrews MM (1997). Baclofen suppression of cocaine self-administration: demonstration using a discrete trials procedure. Psychopharmacology (Berlin) 131: 271-277.

Roberts DC, Andrews MM, Vickers GJ (1996). Baclofen attenuates the reinforcing effects of cocaine in rats. Neuropsychopharmacology 15: 417-423.

Robinson TE, Becker JB (1986). Enduring changes in brain and behavior produced by chronic amphetamine administration: a review and evaluation of animal models of amphetamine psychosis. Brain Res 396: 157-198.

Santiago M, Machado A, Cano J (1993). In vivo release of dopamine from rat striatum, substantia nigra and prefrontal cortex: differential modulation by baclofen. Br J Pharmacol 109: 814-818.

Schneider LH, Alpert JE, Iversen SD (1983). CCK-8 modulation of mesolimbic dopamine: antagonism of amphetamine-stimulated behaviors. Peptides 4: 749-753.

Sharp T, Zetterstrom T, Ljungberg T, Ungerstedt U (1987). A direct comparison of amphetamine-induced behaviours and regional brain dopamine release in the rat using intracerebral dialysis. Brain Res 401: 322-330.

Shoaib M, Swanner LS, Beyer CE, Goldberg SR, Schindler CW (1998). The GABAB agonist baclofen modifies cocaine selfadministration in rats. Behav Pharmacol 9: 195-206.

Shoptaw S, Yang X, Rotheram-Fuller EJ, Hsieh YC, Kintaudi PC, Charuvastra VC et al (2003). Randomized placebo-controlled trial of baclofen for cocaine dependence: preliminary effects for 
individuals with chronic patterns of cocaine use. $J$ Clin Psychiatry 64: 1440-1448.

Sugita S, Johnson SW, North RA (1992). Synaptic inputs to GABAA and $G A B A B$ receptors originate from discrete afferent neurons. Neurosci Lett 134: 207-211.

Tzschentke TM, Schmidt WJ (1998). Discrete quinolinic acid lesions of the rat prelimbic medial prefrontal cortex affect cocaine- and MK-801-, but not morphine- and amphetamineinduced reward and psychomotor activation as measured with the place preference conditioning paradigm. Behav Brain Res 97: 115-127.

Vanderschuren LJ, Kalivas PW (2000). Alterations in dopaminergic and glutamatergic transmission in the induction and expression of behavioral sensitization: a critical review of preclinical studies. Psychopharmacology (Berlin) 151: 99-120.

Ventura R, Cabib S, Alcaro A, Orsini C, Puglisi-Allegra S (2003). Norepinephrine in the prefrontal cortex is critical for amphetamine-induced reward and mesoaccumbens dopamine release. J Neurosci 23: 1879-1885.

Wang JQ, Daunais JB, McGinty JF (1994a). Role of kainate/AMPA receptors in induction of striatal transcription factor and preprodynorphin mRNA by a single injection of amphetamine. Mol Brain Res 27: 118-126.

Wang JQ, Daunais JB, McGinty JF (1994b). NMDA receptors mediate amphetamine-induced upregulation of zif/268 and preprodynorphin mRNA expression in rat striatum. Synapse 18: $43-353$.

Wang JQ, McGinty JF (1995a). Alterations in striatal zif/268, preprodynorphin and preproenkephalin mRNA expression induced by repeated amphetamine administration in rats. Brain Res 673: 262-274.
Wang JQ, McGinty JF (1995b). Dose-dependent alteration in zif/ 268 and preprodynorphin mRNA expression induced by amphetamine or methamphetamine in rat forebrain. $J$ Pharmacol Exp Ther 273: 909-917.

Wang JQ, McGinty JF (1996). Intrastriatal injection of the metabotropic glutamate receptor antagonist MCPG attenuates acute amphetamine-stimulated neuropeptide mRNA expression in rat striatum. Neurosci Lett 218: 13-16.

Wang JQ, McGinty JF (1997). Intrastriatal injection of a muscarinic receptor agonist and antagonist regulates striatal neuropeptide mRNA expression in normal and amphetamine-treated rats. Brain Res 748: 62-70.

Westerink BHC, Santiago M, de Vries JB (1992). In vivo evidence for a concordant response of terminal and dendritic dopamine relase during intranigral infusion of drugs. NS Arch Pharmacol 346: 637-643.

White FJ, Wolf ME (1991). Psychomotor stimulants. In: Pratt JA (ed). The Biological Basis of Drug Tolerance and Dependence. Academic Press: London, pp 153-197.

Zahm DS, Heimer L (1993). Specificity in the efferent projections of the nucleus accumbens in the rat: comparison of the rostral pole projection patterns with those of the core and shell. J Comp Neurol 327: 220-232.

Zetterstrom T, Sharp T, Marsden CA, Ungerstedt U (1983). In vivo measurement of dopamine and its metabolites by intracerebral dialysis: changes after d-amphetamine. J Neurochem 41: 1769-1773.

Zhou W, Mailloux AW, Jung BJ, Edmunds Jr HS, McGinty JF (2004). GABA(B) receptor stimulation decreases amphetamineinduced behavior and neuropeptide gene expression in the striatum. Brain Res 1004: 18-28. 